\title{
Variation in Prognostic Factors and Molecular Phenotype with Menopausal Status in Turkish Patients with Breast Cancer
}

\author{
Hasan MUTLU ${ }^{1}$, Mustafa OZDOGAN ${ }^{2}$, Taner COLAK ${ }^{3}$, Zeki AKCA ${ }^{4}$, Abdullah BUYUKCELIK ${ }^{5}$ \\ ${ }^{1}$ Kayseri Training and Research Hospital, Departmant of Medical Oncology, Kayseri \\ ${ }^{2}$ Akdeniz University, Faculty of Medicine, Medical Oncology Department, Antalya \\ ${ }^{3}$ Akdeniz University, Faculty of Medicine, Departmant of General Surgery, Antalya \\ ${ }^{4}$ Mersin State Hospital, Department of Radiation Oncology, Mersin \\ ${ }^{5}$ Kayseri Acibadem Hospital, Department of Medical Oncology, Kayseri, TURKEY
}

\begin{abstract}
In Turkish patients with breast cancer variations of prognostic factors were examined according to the menopausal status. In addition, molecular variations were investigated according to the menopausal status. A total of 1449 patients was enrolled from Akdeniz University Hospital of Medical School and Kayseri Education and Research Hospital. The patients were divided into three groups as menopausal status (pre, peri and postmenopausal) and into four groups according to molecular types (luminal A,luminal B, HER 2 like and Unclassified-Basal like). Patients were retrospectively recorded in the SPSS software. There was significant difference in the estrogen and cerbB2 hormon receptor positivity between premenopausal and postmenopausal groups ( $\mathrm{p}=0.003$ and 0.032 ). Estrogen receptor ratio was higher in postmenopausal group, and CerbB2 receptor ratio was higher in premenopausal group. Luminal A molecular subtype was the dominant subgroup. Compared to the other two groups, in premenopausal group, the ratio of HER 2 Like and Unclassified-Basal like molecular type were higher and the ratio of the luminal types were lower. Luminal A was the dominant subgroup in Turkish patients with breast cancer. Rate of molecular types was determined to be varied with menopausal status. This variations were compatible with the poor prognosis premenopausal patients with breast cancer.
\end{abstract}

Keywords: Breast cancer, Menopause, Molecular types, Prognosis

\section{ÖZET}

Türk Meme Kanserli Hastalarda Menopozal duruma Göre Prognostik Faktörler ve Moleküler Fenotiplerde Farklılıklar Türk meme kanserli hastalarda menopozal duruma göre prognostik faktörlerin farklliğı incelendi. Ayrıca moleküler farklliklar menopozal duruma göre araştııldı. Akdeniz Üniversitesi ve Kayseri Eğitim ve Araştırma Hastanesi'nden toplam 1449 hasta kaydedildi. Hastalar menopozal duruma göre üç guruba (pre, peri ve postmenopozal) ve moleküler tiplere göre dört guruba (luminal A, luminal B, Her 2 Like ve Sınıflandırılamayan-Basal like) ayrıldı. Hastalar retrospektif olarak SPSS istatistik programına kaydedildi. Moleküler gruplarda Basal Like ve Unclassified grup aynı grup içine alındı. Premenopozal ve postmenopozal gruplar arasında östrojen ve CerbB2 pozitifliği için anlamlı fark mevcuttu ( $p$ değeri 0.003 ve 0.032 , sırası ile). Postmenopozal grupta östrojen reseptörü, premenopozal grupta Cerb B2 oranı daha yüksek idi. Luminal A moleküler alt tip baskın olan altgruptu. 
Diğer iki gurupla karşılaş-tııılığında premenopozal gurupta HER 2 Like ve Sınıflandırılamayan-Basal Like moleküler tiplerin oranı daha fazla, luminal tiplerin oranı daha düşük idi. Türk meme kanserli hastalarda Luminal A baskın olan subgruptu. Moleküler tiplerin oranlarının menopozal status ile farkıılık gösterdiği belirlendi. Bu farklılık premenopozal meme kanserli hastaların kötü prognozu ile uyumluluk göstermekte idi.

Anahtar Kelimeler: Meme kanseri, Menopoz, Moleküler tipler, Prognoz

\section{INTRODUCTION}

There are many factors affecting the prognosis of patients with breast cancer. One of them is age. Age is an important factor for the risk of recurrence independent of other features. ${ }^{1}$ Tumoral features of young age with breast cancer tend to be receptor negative and high-grade..$^{2.3} \mathrm{In}$ addition, rate of $\mathrm{Hu}$ man Epidermal Growth Factor Receptor (HER2 or CerbB2) positive tumors is higher in premenopausal patients. ${ }^{4.5}$ With previous studies, the mean age of natural menopause was determined to be 50-52 years. ${ }^{6}$ Smokers, workers, women who live in high altitudes, nulliparous women undergone hysterectomy enter menopause earlier.-9 Early menarche, high socioeconomic status and use of oral contraceptives are the cause factors of late menopause. ${ }^{8}$ No relation with the race and nutritional status is seen. ${ }^{9}$ The studies conducted in different parts of the world are summarized in Table 1 and median age of menopause is given..$^{10-14}$ The study conducted in Turkish women revealed that mean age of natural menopause is $47.8 \pm 4.0 .{ }^{15}$ Recently, studies conducted in breast cancer recognized different molecular subgroups. In general, these groups are divided into two main groups as the estrogen receptor (ER) positive tumors (luminal A and B) and ER negative tumors (HER2 Like, Basal Like and Unclassified). ${ }^{16}$ Gene expression profile of luminal tumors is similar to those with luminal epithelial structure of normal breast tissue, and the panel of gene expression profile of tumors in basal like group is consistent with gene profile of basal epithelial cell of breast tissue. Luminal A and B groups are the most common molecular sub-groups. Luminal A has the best prognosis, whereas the Basal Like has the worst prognosis. ${ }^{17-21}$ Although tumors with HER2 Like have worse prognosis, HER2 targeted therapies have changed the outcome. In Basal Like tumors, epidermal growth factor receptor (EGFR) and basal cyto-keratin 4,5, and 17 are highly expressed. And also, basal like tumors are associated with breast cancer 1(BRCA1) gene, and Basal Like tumors consisted of about $80 \%$ of BRCA1 positive tumors. ${ }^{22,23}$ Basal Like tumors also has been shown to be associated with menopausal status and the race and the incidence is higher in premenopausal patients of African origin. ${ }^{24-28}$ Molecular sub-groups are summarized in Table 2.

Answers to 3 questions were sought in this study. Firstly variation of the prognostic factors with regard to menopausal status was first investigated in Turkish patients with breast cancer. Second goal was to identify the rate of molecular subtypes in this population. And finally, the correlation between the molecular types of breast cancer and menopausal status was investigated.

\begin{tabular}{|lllll|}
\hline \multicolumn{2}{|l|}{ Table 1. The median age of menopause in different geographic areas } \\
\hline Geographic area & Study selected & $\begin{array}{l}\text { Number of } \\
\text { female }\end{array}$ & Countries & $\begin{array}{l}\text { The median age } \\
\text { of menopause } \\
\text { (years) }\end{array}$ \\
\hline Europe & Dratva et al., 2009 (11) & 5288 & 9 & 54 \\
Latin America & Castelo-Branco et al., 2006 (12) & 17150 & 15 & 48.6 \\
North America & Gold et al., 2001 (13) & 2200 & 1 & 51.4 \\
Asia & Boulet et al., 1994 (14) & 400 & 7 & 51.1 \\
\hline
\end{tabular}




\begin{tabular}{|c|c|c|c|}
\hline Molecular type & Gene Profile & Frequency & Prognosis \\
\hline Luminal $A^{17,18,19,20,21}$ & $\begin{array}{l}\text { ER }(+) \text { and / or PR }(+), \text { HER2 }(-) \\
\text { high expression of ER-related genes, } \\
\text { low expression of the HER2 cluster of genes } \\
\text { low expression of proliferation-related genes }\end{array}$ & $\sim \% 40$ & Best \\
\hline Luminal B ${ }^{20,21}$ & $\begin{array}{l}\text { ER }(+) \text { and / or PR (+), HER2 (-) } \\
\text { lower expression of ER-related genes, } \\
\text { variable expression of the HER2 cluster of genes } \\
\text { higher expression of proliferation-related genes }\end{array}$ & \%20 & Worse than luminal A \\
\hline HER2 Like ${ }^{20.21}$ & $\begin{array}{l}\text { ER (-), PR (-), HER2 (+) } \\
\text { low expression of ER-related genes, } \\
\text { high expression of the HER2 cluster of genes } \\
\text { high expression of proliferation-related genes }\end{array}$ & $10-15 \%$ & Poor prognosis \\
\hline Basal Like $e^{20,21}$ & $\begin{array}{l}\text { ER (-), PR (-), HER2 (-) EGFR (+) or CK4,5,17 (+) } \\
\text { low expression of ER-related genes, } \\
\text { low expression of the HER2 cluster of genes } \\
\text { high expression of proliferation-related genes }\end{array}$ & $15-20 \%$ & Worst prognosis \\
\hline Unclassified & ER (-), PR (-), HER2 (-), EGFR, and CK4,5,17 (-) & $5-15 \%$ & \\
\hline
\end{tabular}

\section{PATIENTS AND METHODS}

A total of 1449 patients was enrolled from Akdeniz University Hospital of Medical School and Kayseri Education and Research Hospital database. Data were retrospectively collected from medical records. The demographic features of the patients were determined.

Menopausal status was divided three groups: premenopausal, perimenopausal and postmenopausal. The patients that have normal menstrual cycles were recorded premenopausal groups. The patients that their follicle-stimulating hormone (FSH) value is $>116 \mathrm{mIU} / \mathrm{ml}$ or amenorrhea for $>12$ months in women over age 45 or have removed bilaterally ovaries were recorded postmenopausal groups. Other patients were considered perimenopausal groups. For evaluating ER (SP1, rabbit monoclonal, Thermoscientific) and progesterone receptor (PR) (SP2, rabbit monoclonal, Thermoscientific), absence of invasive tumor cells staining or nuclear staining less than $5 \%$ were considered negative. It was used ASCO / CAP recommendations to evaluated HER 2 receptor scoring (Neu AB12, Thermo Scientific). Moderate or strong $>30 \%$ membranous staining of tumor cells were considered immunhistochemically strong positive $(+++)$. Weak or no staining were accepted negative. Other staining pattern was considered immunhistochemically $(++)$. if fluorescence in situ hybridization (FISH) was performed,the reason was recorded. The histological grade and nuclear grade were identified according to the modified Bloom-Richardson system. Lymphovascular invasion were investigated as yes / no form. Afterwards, patients were classified according to molecular types. ER (+) and or PR (+), cerbB2 (-) patients were classified as luminal A; ER (+) and or PR (+), cerbB2 (+) cases were classified as luminal B; and ER (-), PR (-) and cerbB2 $(+)$ cases were classified as HER2 like type. Because EGFR study couldn't be performed with CK5 and CK6 in all cases, ER (-), PR (-) and cerbB2 (-) cases were classified as Basal like + Unclassified type. The molecular types were determined according to the total patient group and menopausal groups. The patients were recorded Statistical Package for the Social Sciences 16.0. Frequency analysis, crosstabs, mean, chi square test were performed. $\mathrm{P}$ $<0.05$ was considered significantly. 


\begin{tabular}{|c|c|c|c|c|}
\hline Parameter & $\begin{array}{l}\text { Total } \\
(\mathrm{n}=1422) \\
(\%)\end{array}$ & $\begin{array}{l}\text { Premenopausal } \\
(19 \%) \\
(n=281) \\
n(\%)\end{array}$ & $\begin{array}{l}\text { Perimenopausal } \\
(29 \%) \\
(n=416) \\
n(\%)\end{array}$ & $\begin{array}{l}\text { Postmenopausal } \\
(52 \%) \\
(n=745) \\
n(\%)\end{array}$ \\
\hline \multicolumn{5}{|l|}{ Stage } \\
\hline 1 & 22.6 & $61(22 \%)$ & 99 (24\%) & 168 (22\%) \\
\hline 2 & 39.6 & 102 (36\%) & 189 (46\%) & 281 (38\%) \\
\hline 3 & 30.8 & $100(36 \%)$ & $114(27 \%)$ & 229 (31\%) \\
\hline 4 & 1.2 & $3(\% 1)$ & $5(\% 1)$ & $10(\% 1)$ \\
\hline Unknown & 5.8 & $15(5 \%)$ & $9(\%$ 2) & 57 (8\%) \\
\hline \multicolumn{5}{|c|}{ Estrogen receptor } \\
\hline Positive & 54.5 & 129 (46\%) & 233 (56\%) & 426 (57\%) \\
\hline Negative & 30.9 & $101(36 \%)$ & $134(32 \%)$ & $200(27 \%)$ \\
\hline Unknown & 14.6 & $51(18 \%)$ & 49 (12\%) & 119 (16\%) \\
\hline \multicolumn{5}{|c|}{ Progesterone receptor } \\
\hline Positive & 55.5 & $154(55 \%)$ & 249 (60\%) & $389(52 \%)$ \\
\hline Negative & 28.8 & 75 (27\%) & $113(27 \%)$ & 226 (30\%) \\
\hline Unknown & 15.7 & $52(18 \%)$ & $54(13 \%)$ & 130 (18\%) \\
\hline \multicolumn{5}{|l|}{ CerbB2 } \\
\hline Positive & 22.8 & 69 (25\%) & 100 (24\%) & $159(21 \%)$ \\
\hline Negative & 54.5 & 127 (45\%) & 234 (56\%) & $426(57 \%)$ \\
\hline Unknown & 22.8 & 85 (30\%) & $82(20 \%)$ & $160(22 \%)$ \\
\hline \multicolumn{5}{|c|}{ Histological Grade } \\
\hline 1 & 6.4 & $16(6 \%)$ & $31(7 \%)$ & $46(6 \%)$ \\
\hline 2 & 37.6 & 107 (38\%) & 168 (40\%) & 268 (36\%) \\
\hline 3 & 26.6 & 77 (27\%) & 110 (26\%) & 196 (26\%) \\
\hline Unknown & 29.4 & 81 (29\%) & 107 (27\%) & 235 (32\%) \\
\hline \multicolumn{5}{|c|}{ Nuclear Grade } \\
\hline 1 & 7.0 & $18(6 \%)$ & $33(8 \%)$ & $50(7 \%)$ \\
\hline 2 & 45.8 & 124 (44\%) & 195 (47\%) & 343 (46\%) \\
\hline 3 & 18.6 & 59 (21\%) & 87 (21\%) & 122 (16\%) \\
\hline Unknown & 28.6 & 80 (29\%) & 101 (24\%) & $230(31 \%)$ \\
\hline \multicolumn{5}{|l|}{ Breast } \\
\hline Right & 45.8 & 143 (51\%) & 194 (46\%) & 331 (45\%) \\
\hline Left & 54.2 & 138 (49\%) & 222 (54\%) & 414 (55\%) \\
\hline \multicolumn{5}{|c|}{ Family History } \\
\hline Yes & 6.9 & $22(8 \%)$ & $35(9 \%)$ & $43(5 \%)$ \\
\hline None & 75.7 & 200 (71\%) & 313 (75\%) & 578 (78\%) \\
\hline Unknown & 17.4 & 59 (21\%) & 68 (16\%) & 124 (17\%) \\
\hline
\end{tabular}




\begin{tabular}{|c|c|c|c|}
\hline Parameter & $\begin{array}{l}\text { P value } \\
\text { Premenopausal vs. } \\
\text { Perimenopausal }\end{array}$ & $\begin{array}{l}\text { P value } \\
\text { Premenopausal vs. } \\
\text { Postmenopausal }\end{array}$ & $\begin{array}{l}\text { P value } \\
\text { Perimenopausal vs. } \\
\text { Postmenopausal }\end{array}$ \\
\hline Stage & 0.147 & 0.727 & 0.561 \\
\hline Estrogen receptor & 0.122 & 0.003 & 0.334 \\
\hline Progesterone receptor & 0.579 & 0.452 & 0.193 \\
\hline CerbB2 & 0.209 & 0.032 & 0.371 \\
\hline Histological Grade & 0.658 & 0.907 & 0.690 \\
\hline Nuclear Grade & 0.811 & 0.293 & 0.372 \\
\hline Family History & 0.954 & 0.344 & 0.218 \\
\hline Breast & 0.219 & 0.094 & 0.521 \\
\hline
\end{tabular}

\section{RESULTS}

The mean age of patients was $53 \pm 12$. Early stage rate was $62.2 \%$ and rate of locally advanced stage was $30.8 \%$, and metastatic stage rate was $1.2 \%$. ER positivity was determined to be $54.5 \%$, PR positivity was found to be $55.5 \%$, and CerbB2 positivity was determined to be $22.8 \%$. According to the grades of tumor, the incidence of histological grade 2 was $37.6 \%$ and the incidence of nuclear grade 2 was $45.8 \%$, and this degrees of grades are the most common grade types. The incidence of primary location of tumor was higher in left breast with the rate of $54.2 \%$. The rate of patients with family history was $6.9 \%$. Demographic and prognostic features and menopausal status are shown in Table 3.

At the time of diagnosis, the rate of early stage in all patients was $62.2 \%$, and this rate was $22 \%$ in the premenopausal group and $4 \%$ in menopausal group and $22 \%$ in postmenopausal group. When the groups were compared by menopausal patients in terms of prognostic factors, there was a significant difference in ER and CerbB2 positivity between premenopausal and postmenopausal groups ( $\mathrm{p}$ value 0.003 and 0.032 ). ER positivity was significantly higher in postmenopausal group with the rate of $57 \%$. CerbB2 ratio was higher in premenopausal group ( $25 \%$ vs. $21 \%)$. The statistical p values between menopausal groups and prognostic factors were shown in Table 4. The rate of luminal molecular subtypes are classified according to stage at the time of diagnosis in Table 5. Patients with missing registration information were not included in this study. Luminal A had the highest inicidence with the rate of $37.53 \%$ in Turkish patients with breast cancer. When the total of 965 patients were exami-

\begin{tabular}{|c|c|c|c|c|}
\hline$(n=965)$ & $\begin{array}{l}\text { Luminal A }(n=366) \\
(n / \%)\end{array}$ & $\begin{array}{l}\text { Luminal B }(n=247) \\
(n / \%)\end{array}$ & $\begin{array}{l}\text { HER2 Like }(n=133) \\
(n / \%)\end{array}$ & $\begin{array}{l}\text { BL or Unclas. }(n=219) \\
(n / \%)\end{array}$ \\
\hline Stage $1(n=227)$ & $112(31 \%)$ & 52 (21\%) & 31 (23\%) & 32 (15\%) \\
\hline Stage $2(n=398)$ & 143 (39\%) & 99 (40\%) & $41(31 \%)$ & 115 (52\%) \\
\hline Stage $3(n=327)$ & 105 (29\%) & 91 (37\%) & 59 (44\%) & 72 (33\%) \\
\hline Stage $4(n=13)$ & $6(1 \%)$ & $5(2 \%)$ & $2(2 \%)$ & $0(0 \%)$ \\
\hline
\end{tabular}




\begin{tabular}{|lllll|}
\hline \multicolumn{7}{|l|}{ Table 6. Rates of molecular subtypes in study population and subgroups } \\
\hline & Luminal A & Luminal B & HER 2 Like & Basal like or Unclassified \\
\hline Study Population $(n=983)$ & $37.53 \%$ & $25.53 \%$ & $14.03 \%$ & $22.88 \%$ \\
Premenopausal $(n=190)$ & $28.42 \%$ & $25.26 \%$ & $18.42 \%$ & $27.89 \%$ \\
Perimenopausal $(n=283)$ & $37.10 \%$ & $28.26 \%$ & $11.30 \%$ & $23.32 \%$ \\
Postmenopausal $(n=510)$ & $41.17 \%$ & $24.11 \%$ & $13.92 \%$ & $20.78 \%$ \\
\hline
\end{tabular}

ned, Luminal A predominated in stage I, II and III. The incidence of HER Like molecular subtypes was higher in stage 3 with a rate of $44 \%$, and incidence of Basal Like or Unclassified type was higher in stage 2 with the rate of $52 \%$. A significant difference was found between molecular subtypes and the menopausal status. There was a significant difference in molecular types between premenopausal group and the other two groups $(\mathrm{p}=0.047$ in premenopausal vs. perimenopausal groups, and $\mathrm{p}=$ 0.012 in premenopausal vs postmenopausal groups). There was no significant difference between perimenopausal and postmenopausal groups $(\mathrm{p}=$ 0.323). The rate of Basal Like and HER 2 Like or unclassified molecular types were higher, and the rate of Luminal types was lower in premenopausal group than in the other two groups. (The rate of Luminal A + B were $54 \%$ in premenopausal group, $65 \%$ in perimenopausal group and $65 \%$ in postmenopausal group). Table 6 shows the molecular types for the menopausal status.

\section{DISCUSSION}

When we examined Turkish patients with breast cancer, there was a significant difference in the receptor expression between premenopausal and postmenopausal groups. ER positivity was $46 \%$ in premenopausal group, and this rate was significantly higher in postmenopausal group with the rate of $57 \%(\mathrm{p}=0.003)$. CerbB2 ratio was higher in premenopausal group ( $25 \%$ vs. $21 \%)(\mathrm{p}=0.032)$. There were no significant differences in terms of other factors. The molecular types of Turkish patients with breast cancer was first evaluated extensively in this study. In the overall groups, rate of luminal A was $38 \%$, rate of luminal B was $26 \%$, rate of HER 2 Like was $14 \%$ and the rate of Basal Like
+ Unclassified group was 23\%. In Literature, luminal A was usually reported to be the most common molecular sub-type with the rate of approximately $40 \%$ in patients with breast cancer, similarly luminal A was the most common sub-type in our patient population. In a study including 1279 patients, it was determined that the rate of luminal $\mathrm{A}$ was $65.8 \%$, the rate of luminal B was $14.3 \%$, the rate of HER2Like type was $4.9 \%$, and the rate of Basal Like type was $10.4 \%$, and the rate of unclassified group was $4.6 \% .{ }^{29} \mathrm{~A}$ significant difference was detected in molecular types between premenopausal group and the other two groups, and no significant difference was determined between perimenopausal and postmenopausal women. Luminal A was higher in luminal category in all menopausal group. Rates of Basal Like and HER 2 Like or unclassified molecular types were higher, and the rate of Luminal types was lower in premenopausal group than in the other two groups. In previous studies it was noted that HER2 Like and Basal Like molecular sub-groups had a worse prognosis. ${ }^{29-31}$ Lower rate of total luminal types in premenopausal than that of peri- and post-menopausal groups, and also the higher rates of total HER 2 Like and Basal Like + Unclassified groups can be considered to be one of the explanatory reasons of well-known poor prognosis in premenopausal patients group.

Molecular types of Turkish patients with breast cancer were first given in our study. Secondly, it was investigated that whether the molecular types in patients with breast cancer vary with menopausal status. According to the result of our study, rates of molecular types were compatible with the poor prognosis of premenopausal patients group. 


\section{Acknowledgement:}

\section{The authors would like to thank İsa Doğan.}

\section{REFERENCES}

1. Han W, Kim SW, Park IA, et al. Young age: An independent risk factor for disease-free survival in women with operable breast cancer. BMC Cancer 4: 82-89, 2004.

2. Gajdos C, Tartter PI, Bleiweiss IJ, et al. Stage 0 to stage III breast cancer in young women. J Am Coll Surg 190: 523-529, 2000.

3. Colleoni M, Rotmensz N, Robertson C, et al. Very young women ( $<35$ years) with operable breast cancer: Features of disease at presentation. Ann Oncol 13: 273-279, 2002.

4. Love RR, Duc NB, Dinh NV, et al. Young age as an adverse prognostic factor in premenopausal women with operable breast cancer. Clin Breast Cancer 2: 294298, 2002.

5. Anders CK, Hsu DS, Broadwater G, et al. Young age at diagnosis correlates with worse prognosis and defines a subset of breast cancers with shared patterns of gene expression. J Clin Oncol 26: 3324-3330, 2008.

6. Nappi RE, Wawra K, Schmitt S. Hypoactive sexual desire disorder in postmenopausal women. Gynecol Endocrinol 22: 318-323, 2006.

7. McKinlay SM. The normal menopause transition: an overview. Maturitas 23: 137-145, 1996.

8. Atasu T, Ozekici U, Hekim N. Menopoz Tedavisi ve Kanser. Nobel Tip Kitabevleri, Istanbul, 2001: 295298.

9. Jonathan S. Berek. Novak's Gynecology. Çeviri Editörü: Ahmet Erk, Novak Jinekoloji, Nobel Tıp Kitabevleri, Istanbul, 2004: 1109-1139.

10. Palacios S, Henderson WW, Siseles N, et al. Age of menopause and impact of climacteric symptoms by geographical region. Climacteric 13: 419-428, 2010.

11. Dratva J, Go'mez Real F, Schindler C, et al. Is age at menopause increasing across Europe? Results on age at menopause and determinants from two populationbased studies. Menopause 16: 385-394, 2009.

12. Castelo-Branco C, Blumel JE, Chedraui P, et al. Age at menopause in Latin America. Menopause 13: 706712, 2006.

13. Gold EB, Bromberger J, Crawford S, et al. Factors associated with age at natural menopause in a multiethnicsample of midlife women. Am J Epidemiol 153: 865-874, 2001.

14. Boulet MJ, Oddens BJ, Lehert P, et al. Climacteric and menopause in seven Southeast Asian countries. Maturitas 19: 157-176, 1994.

15. Neslihan Carda S, Bilge SA, Ozturk TN, et al. The menopausal age, related factors and climacteric symptoms in Turkish women. Maturitas 30: 37-40, 1998.
16. Sorlie T, Perou CM, Tibshirani R, et al. Gene expression patterns of breast carcinomas distinguish tumor subclasses with clinical implications. Proc Natl Acad Sci USA 98: 10869-10874, 2001.

17. Fan C, Oh DS, Wessels L, et al. Concordance among gene-expression-based predictors for breast cancer. N Engl J Med 355: 560-569, 2006.

18. Hu Z, Fan C, Oh DS, et al. The molecular portraits of breast tumors are conserved across microarray platforms. BMC Genomics 7: 96-108, 2006.

19. Loi S, Haibe-Kains B, Desmedt C, et al. Definition of clinically distinct molecular subtypes in estrogen receptor-positive breast carcinomas through genomic grade. J Clin Oncol 25: 1239-1246, 2007.

20. Voduc KD, Cheang MC, Tyldesley S, et al. Breast cancer subtypes and the risk of local and regional relapse. J Clin Oncol 28: 1684-1691, 2010.

21. Carey LA, Perou CM, Livasy CA, et al. Race, breast cancer subtypes, and survival in the Carolina Breast Cancer Study. JAMA 295: 2492-2502, 2006.

22. Foulkes WD, Brunet JS, Stefansson IM, et al. The prognostic implication of the basal-like (cyclin E high/p27 low/p53+/glomeruloid-microvascular-proliferation+) phenotype of BRCA1-related breast cancer. Cancer Res 64: 830-835, 2004.

23. Foulkes WD, Stefansson IM, Chappuis PO, et al. Germline BRCA1 mutations and a basal epithelial phenotype in breast cancer. J Natl Cancer Inst 95: 14821485, 2003.

24. Parker JS, Mullins M, Cheang MC, et al. Supervised Risk Predictor of Breast Cancer Based on Intrinsic Subtypes. J Clin Oncol 27: 1160-1167, 2009.

25. Millikan RC, Newman B, Tse CK, et al. Epidemiology of basal-like breast cancer. Breast Cancer Res Treat 109: 123-139, 2008.

26. Morris GJ, Naidu S, Topham AK, et al. Differences in breast carcinoma characteristics in newly diagnosed African-American and Caucasian patients: a singleinstitution compilation compared with the National Cancer Institute's Surveillance, Epidemiology, and End Results database. Cancer 110: 876-884, 2007.

27. Bauer KR, Brown M, Cress RD, et al. Descriptive analysis of estrogen receptor (ER)-negative, progesterone receptor (PR)-negative, and HER2-negative invasive breast cancer, the so-called triple-negative phenotype: a population-based study from the California cancer Registry. Cancer 109: 1721-1728, 2007.

28. Lund MJ, Trivers KF, Porter PL, et al. Race and triple negative threats to breast cancer survival: a population-based study in Atlanta, GA. Breast Cancer Res Treat 113: 357-370, 2009.

29. Dawood S, Hu R, Homes MD, et al. Defining breast cancer prognosis based on molecular phenotypes: results from a large cohort study. Breast Cancer Res Treat 126: 185-192, 2011. 
30. Cheang MCU, Voduc D, Bajdik C et al. Basal-like breast defined by five biomarkers has superior prognostic value than triple-negative phenotype. Clin Cancer Res 14: 1368-1376, 2008

31. Sorlie T, Perou CM, Tibshirani R et al. Gene expression patterns of breast carcinomas distinguish tumor subclasses with clinical implications. Proc Natl Acad Sci USA 98: 10869-10874, 2001.

\section{Correspondence}

Dr. Hasan MUTLU

Kayseri Eğitim ve Araştırma Hastanesi

Tıbbi Onkoloji Bölümü

Melikgazi

KAYSERI / TURKEY

Tel: (+90.532) 6958357

Fax: (+90.352) 3207313

e-mail: doktorhasanmutlu@gmail.com 